\title{
Article \\ The Use of Colistin in Food-Producing Animals in Estonia-Vaccination as an Effective Alternative to Consumption of Critically Important Antimicrobials in Pigs
}

\author{
Marju Sammul ${ }^{1,2, *}$, Kerli Mõtus ${ }^{1}\left(\mathbb{D}\right.$ and Piret Kalmus ${ }^{1}$ \\ 1 Institute of Veterinary Medicine and Animal Sciences, Estonian University of Life Sciences, Kreutzwaldi 62, \\ 51006 Tartu, Estonia; kerli.motus@emu.ee (K.M.); piret.kalmus@emu.ee (P.K.) \\ 2 State Agency of Medicines, Nooruse 1, 50411 Tartu, Estonia \\ * Correspondence: marju.sammul@ravimiamet.ee
}

\section{check for} updates

Citation: Sammul, M.; Mõtus, K.; Kalmus, P. The Use of Colistin in Food-Producing Animals in Estonia-Vaccination as an Effective Alternative to Consumption of Critically Important Antimicrobials in Pigs. Antibiotics 2021, 10, 499. https://doi.org/10.3390/ antibiotics10050499

Academic Editors: Jeroen Dewulf and Marc Maresca

Received: 25 February 2021

Accepted: 24 April 2021

Published: 28 April 2021

Publisher's Note: MDPI stays neutral with regard to jurisdictional claims in published maps and institutional affiliations.

Copyright: (c) 2021 by the authors. Licensee MDPI, Basel, Switzerland. This article is an open access article distributed under the terms and conditions of the Creative Commons Attribution (CC BY) license (https:/ / creativecommons.org/licenses/by/ $4.0 /)$.

\begin{abstract}
Reducing the use of critically important antimicrobials in veterinary medicine is increasingly important to avoid the development and spread of antimicrobial resistance. The aim of this study was to analyse ten-year trends of colistin consumption in Estonia and to ascertain the possible association between Escherichia (E.) coli vaccination and colistin consumption in pig production. Colistin sales data (2010-2019) were collected from the wholesalers, allowing differentiation of target species. In Estonia, the amount of sold colistin increased constantly and almost doubled from 2010 to 2013, and decreased from 2013 to 2019 by $92.5 \%$ in total. On average across a ten-year study period, $89.7 \%$ of colistin was used in pig production. The number of sold doses of $E$. coli vaccines for pigs was very low before $2014(<2000)$ and increased drastically to $2019(362,000)$. According to linear time-series model with autoregressive integrated moving average (ARIMA) the consumption of colistin in pigs decreased on average by $0.23 \mathrm{mg} / \mathrm{PCU}$ for every $10,000 \mathrm{E}$. coli vaccine doses $(95 \%$ $\mathrm{CI}-0.39,-0.06 ; p=0.006$ ) over ten years. This study revealed that in pig production, vaccination against $E$. coli strains contributes to the expected downward trend in colistin consumption.
\end{abstract}

Keywords: colistin; Escherichia coli vaccination; national statistics; pigs

\section{Introduction}

Lists of critically important antimicrobials (CIAs) according to their importance in human and veterinary medicine are created at the international, regional, and national level [1], and polymyxins are predominantly classified as the highest priority CIAs to human medicine [2,3]. One of these in clinical use is colistin (polymyxin E), which was discovered in 1949 [4] and has been used in both human and veterinary medicine $[5,6]$. In animals, colistin has been widely used in pig production $[7,8]$ for the treatment and prevention of post-weaning diarrhea [9-11] caused by E. coli. E. coli-induced diseases are responsible for economic losses in pig production as they cause high morbidity and mortality among piglets [12]. In human medicine, due to the shortly afterwards discovered systemic toxicity, the use of colistin was limited [13] and the risk for the zoonotic transfer of resistance genes and resistant bacteria was estimated low. Therefore, colistin has been used extensively in veterinary medicine as group treatment or for the prevention of diseases [10] for many years.

The development of colistin resistance has been associated with the non-transferable genome-mediated mutation. In 2015, a plasmid-mediated gene, mcr-1 was identified in gram-negative bacteria, such as E. coli and Salmonella spp., which made a transfer of polymyxin resistance easier. The $m c r-1$ was found in several countries from various origins including farm animals, raw meat, and humans [14-16]. In Estonia, mcr-1 was isolated from a pig slurry sample in 2015 [17]. In recent years, systemic colistin treatment in humans has been re-introduced. In 2016, the European Medicines Agency (EMA) updated the 
advice on the impact of colistin use for human and animal health and raised the level of the overall probability of transfer of colistin-resistant bacteria from low to high [18] and the World Health Organization (WHO) re-classified polymyxins as the highest priority CIAs for human medicine. Colistin has become an important antimicrobial for the treatment of infections caused by multidrug-resistant gram-negative bacteria $[19,20]$-the last-resort antimicrobial critically important for human health, which uses in animals should be restricted [3].

The global spread of colistin-resistant bacteria requires decisive action in reducing the use of colistin in livestock and particularly in pig production. Some countries like the Netherlands, which had significantly reduced their antimicrobial use (AMU) in animal production, had shown lowered E. coli resistance levels in pig production [21]. The major policy changes like the withdrawal of colistin as a feed additive are important steps on reducing colistin resistance and have shown great impact on the use of colistin in China after the ban of colistin use as a growth promoter in 2017 [22]. The European Union (EU) banned the use of all antimicrobial growth-promoters in animal feed for all EU countries already in 2006 [23]. Nevertheless, the total prohibition of some antimicrobials may not lead to the desired result, the demanding continuous reduction of CIAs may cause an increase in the use of other antimicrobials [24,25].

The increased antimicrobial resistance (AMR) among animal and human pathogens has promoted the search for alternatives. One of such is the herd-level application of vaccination programmes. Several studies have demonstrated the potential of vaccines to achieve a significant reduction of antimicrobial consumption in swine herds [26,27]. Vaccination of pigs against different pathogens as Actinobacillus pleuropneumonia [28], Lawsonia intracellularis [29], porcine circovirus type 2 [30,31], porcine reproductive and respiratory syndrome virus [32] can lead to the remarkable decrease of AMU. The effect of vaccination in swine herds on the use of polymyxins has been studied in combination with other alternatives [33]. However, we are not aware of any published studies addressing the association between E. coli vaccination of swine herds and the consumption of colistin.

The use of colistin and other CIAs is not prohibited in animals in Estonia. However, the instructions for the prudent use of antimicrobials are publicly available since 2012 [34] and the Estonian Ministry of Rural Affairs published the treatment guidelines with strong recommendations to avoid CIAs for the treatment of food-producing animals [35]. The comprehensive analysis revealing the time-trends of colistin consumption in Estonian production animals is missing. The aim of the study was to analyse the use of colistin in food-producing animals in the years 2010-2019 in Estonia and to identify the possible association between vaccination of piglets against E. coli and consumption of colistin in pigs.

\section{Results}

Out of polymyxins, only colistin sulfate was sold in Estonia during our observation period. In 2010-2019, five different nationally authorized colistin-containing veterinary medicinal products, indicated for oral administration to pigs, cattle (calves), and poultry, were sold. Three of them were sold throughout the 10-years study period. For two of them, there was a one-time sale in 2015 and in 2019.

In 2010-2019, vaccines for pigs from ATC group immunologicals for Suidae (QI09), containing E. coli component, were sold with two ATCvet codes: inactivated bacterial vaccines containing E. coli components with ATCvet code QI09AB02, and inactivated bacterial vaccines containing both $E$. coli components and Clostridium components with ATCvet code QI09AB08.

\subsection{The Sales of Colistin by Animal Species in 2010-2019}

The total sales of colistin both in kilograms and in mg/PCU increased from 2010 to 2013 and have decreased steadily since 2014 (Table 1). The proportion of colistin from all sold antimicrobials (\% of total AM) was highest in 2013 (8.1\%) and during 2015-2019 has 
ranged between $0.7-1.7 \%$. The overall use of colistin decreased from $378 \mathrm{~kg}$ to $53 \mathrm{~kg}$ (by $86.0 \%$ ) during the whole period.

Table 1. Sales of colistin for food-producing animals in Estonia in years 2010-2019.

\begin{tabular}{ccccccccccc}
\hline Sold Colistin & $\mathbf{2 0 1 0}$ & $\mathbf{2 0 1 1}$ & $\mathbf{2 0 1 2}$ & $\mathbf{2 0 1 3}$ & $\mathbf{2 0 1 4}$ & $\mathbf{2 0 1 5}$ & $\mathbf{2 0 1 6}$ & $\mathbf{2 0 1 7}$ & $\mathbf{2 0 1 8}$ & $\mathbf{2 0 1 9}$ \\
\hline Total sales, kg & 378 & 458 & 570 & 709 & 403 & 164 & 95 & 127 & 95 & 53 \\
\% of total AM & 4.6 & 5.5 & 7.3 & 8.1 & 4.1 & 1.7 & 1.1 & 1.7 & 1.3 & 0.7 \\
Total sales, mg/PCU & 3.51 & 4.31 & 4.88 & 5.75 & 3.12 & 1.33 & 0.73 & 1.14 & 0.83 & $\mathrm{n} / \mathrm{a}$ \\
For pigs, kg & 336 & 425 & 517 & 651 & 377 & 99 & 86 & 118 & 89 & 42 \\
\% of total colistin & $89 \%$ & $93 \%$ & $91 \%$ & $92 \%$ & $93 \%$ & $60 \%$ & $91 \%$ & $93 \%$ & $93 \%$ & $79 \%$ \\
For cattle and poultry, $\mathrm{kg}$ & 22 & 18 & 42 & 32 & 8 & 54 & 4 & 7 & 4 & 6 \\
\% of total colistin & $6 \%$ & $4 \%$ & $7 \%$ & $5 \%$ & $2 \%$ & $33 \%$ & $4 \%$ & $5 \%$ & $5 \%$ & $12 \%$ \\
For species unknown, $\mathrm{kg}$ & 20 & 15 & 11 & 26 & 18 & 11 & 5 & 2 & 2 & 5 \\
\% of total colistin & $5 \%$ & $3 \%$ & $2 \%$ & $4 \%$ & $5 \%$ & $7 \%$ & $6 \%$ & $2 \%$ & $2 \%$ & $9 \%$ \\
\hline
\end{tabular}

In 2010-2019, the sales of colistin for pigs accounted for $60-93 \%$ of the total consumption of colistin, while on average $6.5 \%$ were sold for cattle and poultry (Table 1 ). The quantities of colistin used in pigs, almost doubled by 2013 compared to 2010 and thereafter, a sharp drop in 2014-2015. The colistin sales for pigs decreased from 2010 to 2019 by $87.5 \%$ in total (Figure 1). The sales for cattle and poultry fluctuated slightly, showing a decrease of $72.7 \%$ in total. The target species remained unknown for $3.8 \%$ of sold colistin across the ten-year period. The colistin sales for unknown species decreased by $75.0 \%$ in total (Table 1).

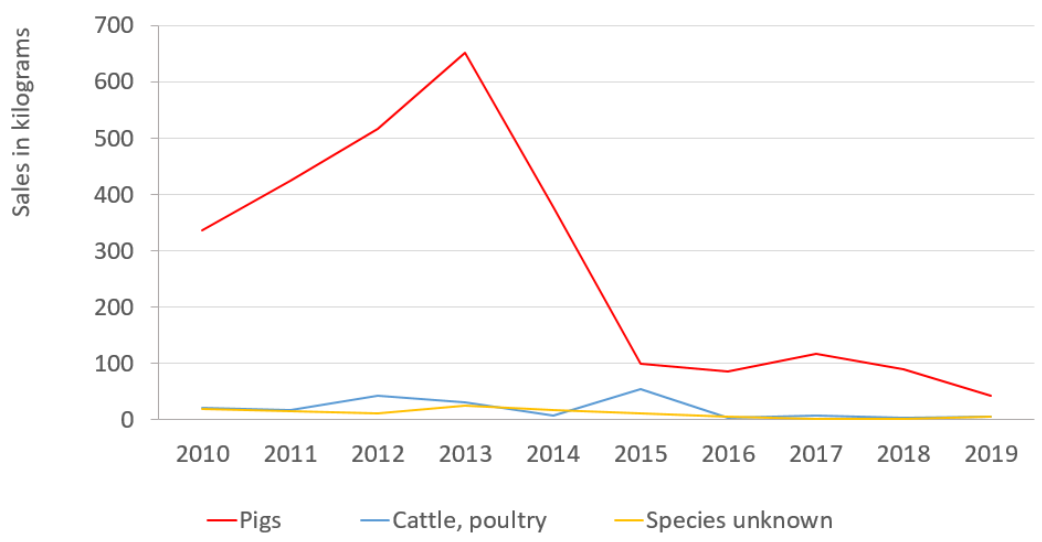

Figure 1. Sales of colistin (kg) by animal species in years 2010-2019, in Estonia.

\subsection{Association between Vaccination of Piglets Against E. coli and Consumption of Colistin in Pigs}

In 2010-2013, the average number of piglets born in Estonia per year was 765,000 [36], while the number of sold doses of E. coli vaccines for pigs with ATCvet code QI09AB02 remained under 2000. From 2013 to 2019, the number of sold vaccine doses increased to 362,000 (Table 2, Figure 2). In 2013, the consumption of colistin in pigs was $13.88 \mathrm{mg} / \mathrm{PCU}$ (Table 2). In the first years of active vaccination, in 2014-2015, colistin use in pigs decreased to $7.77 \mathrm{mg} / \mathrm{PCU}$ and $2.20 \mathrm{mg} / \mathrm{PCU}$ respectively and remained considerably lower in 2015-2019 compared to 2010-2014 (Table 2, Figure 2).

Table 2. Sales of colistin and E. coli vaccines for pigs and number of piglets in Estonia in years 2010-2019.

\begin{tabular}{|c|c|c|c|c|c|c|c|c|c|c|}
\hline Characteristic & 2010 & 2011 & 2012 & 2013 & 2014 & 2015 & 2016 & 2017 & 2018 & 2019 \\
\hline PCUpigs (in 1000 tonnes) & 35 & 34 & 43 & 47 & 49 & 45 & 38 & 37 & 40 & 42 \\
\hline Colistin for pigs (in mg/PCU) & 9.63 & 12.47 & 12.14 & 13.88 & 7.77 & 2.20 & 2.27 & 3.15 & 2.23 & 1.00 \\
\hline Produced piglets (in 1000 heads) & 752 & 782 & 775 & 750 & 774 & 744 & 592 & 624 & 621 & $\mathrm{n} / \mathrm{a}$ \\
\hline Escherichia (in 1000 doses) & 0.8 & 1.7 & 0.8 & 2 & 220 & 325 & 209 & 301 & 349 & 362 \\
\hline Escherichia + Clostridium (in 1000 doses) & 42 & 75 & 50 & 83 & 83 & 72 & 77 & 67 & 73 & 65 \\
\hline
\end{tabular}




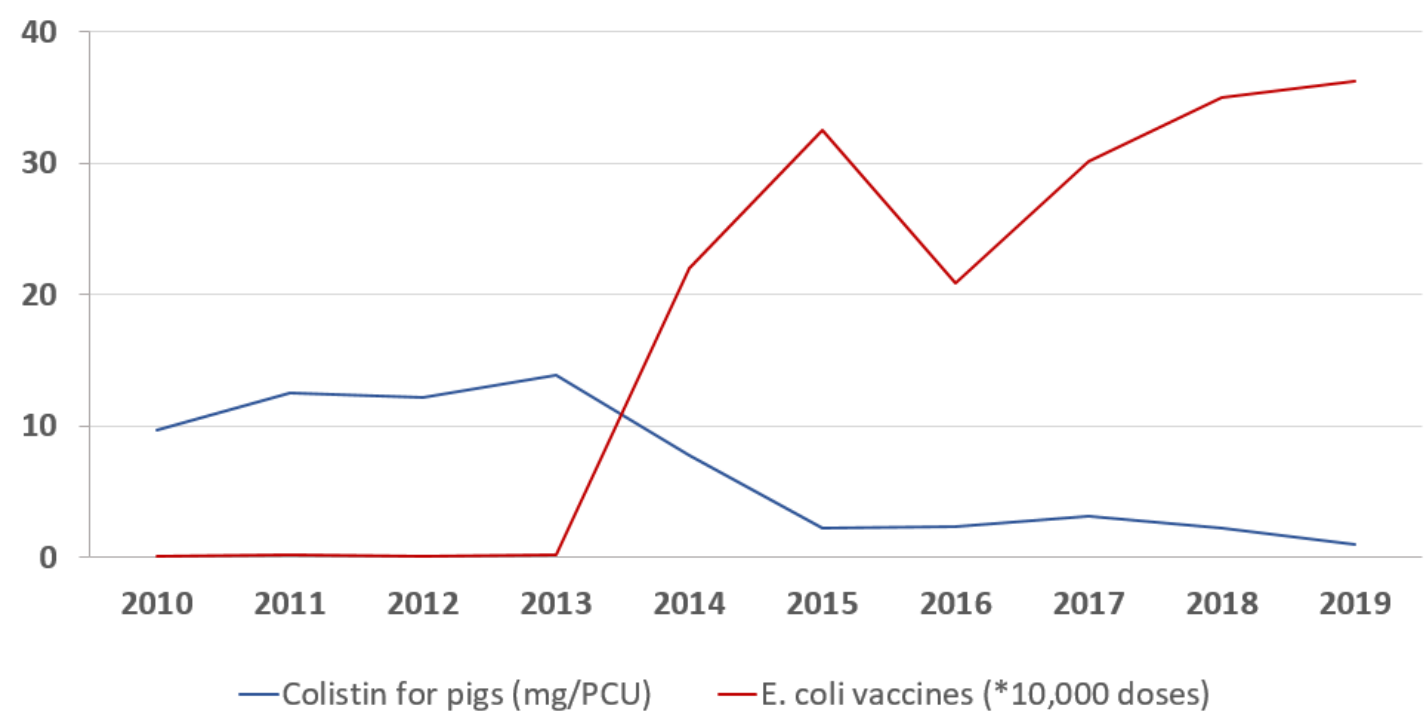

Figure 2. Consumption of colistin and Escherichia coli vaccines for pigs in $2010-2019\left({ }^{*}\right.$ vaccines are presented in 10,000 doses, colistin is presented in $\mathrm{mg} / \mathrm{PCU})$.

According to the time-series ARIMA model the consumption of colistin decreased on average by $0.23 \mathrm{mg} / \mathrm{PCU}$ for every 10,000 vaccine doses ( $95 \% \mathrm{CI}-0.39,-0.06 ; p=0.006$ ).

\section{Discussion}

Globally, major policy changes have followed the discovery of $m c r-1$ and the reclassification of polymyxins as the highest priority CIAs for human medicine. The important step implemented in several countries worldwide is a withdrawal of colistin as a feed additive in animals. This has already resulted in a reduction in colistin use in China [22]. In Europe, between 2011 and 2018, sales of polymyxins decreased by 69.8\% in European Union/European Economic Area (EU/EEA) countries overall [37]. There is little information available about how this decrease was achieved in various countries. Denmark, for example, uses for pigs the VetStat "yellow card initiative" monitoring system $[25,38,39]$, which warns against the overuse of antimicrobials. There was a large drop in the use of polymyxins in Spain and Italy, on which a brief summary by country is published by the European Surveillance of Veterinary Antimicrobial Consumption (ESVAC) [40]. Estonia reduced sales of polymyxins remarkably and achieved in 2018 twice-lower level as the median in 31 European countries.

The present study revealed that a remarkable increase of colistin use from 2010 to 2013 in Estonia and a sharp reduction thereafter, was largely the result of changes in colistin use in pigs. In addition, we ascertained a significant association between increased vaccination of piglets against $E$. coli and reduction of colistin use. In addition to improved rearing conditions and feeding, vaccination of piglets against $E$. coli strains has been shown as an effective alternative to control post-weaning diarrhea at the farmlevel [41]. However, in most cases, successful disease prevention and an expected decrease in AMU is not achieved by a single alternative measure. Raasch et al. [33] assessed the effectiveness of alternative measures in pig production, such as improvement of biosecurity, vaccination, improved feeding, and health care, and found a significant reduction in colistin consumption as the result of the implementation of different measures. Due to the design of our study and the absence of farm-level information, we could not draw a clear causeand-effect relationship here, but the association between vaccination and colistin used was evident. Due to unknown reasons, E. coli vaccines were underused before 2014 in Estonia, and a simultaneous increase in vaccination and decreased colistin consumption in pigs was confirmed.

The reduction in colistin use could also be explained to some extent by the change in pig herd structure in Estonia over the study period. The number of small pig producers 
( $<3000$ pigs) increased 6-hold and the total number of pigs increased by $21 \%$ by 2014 compared to 2010. Due to the emergence of African Swine Fever (ASF) in Estonia in 2014 [42], the number of pigs decreased and a large proportion of smaller pig producers ceased production within 2014-2019. Different size pig farms might deviate in regards to their animal health and welfare as well as overall attitudes towards AMU and vaccination. However, by now the number of pigs in Estonia has recovered and remains only about $1 \%$ lower than at the start of the current study [43]. In 2015, comprehensive and rigorous biosecurity measures were implemented in pig farms due to ASF and this possibly changed the mentality of the farmers to act more proactively in disease prevention. Due to the personal decision-making process, further studies should be directed to reveal the triggers and motivation of pig farmers and veterinarians to change their farm rearing conditions and treatment practices.

In Estonia, general policymaking decisions about the regulation of AMU at a national level have not been taken. Therefore, all changes in AMU are primarily explained by the behavior and attitude of veterinarians and farmers. The number of veterinarians working in the pig industry is not high in Estonia, and close personal contacts between these groups may support a better understanding of antimicrobial treatment and herd health management, also promoting the use of vaccines. One possible explanation may be the increase of awareness through the educational courses on the topics of prudent use of antimicrobials and improvement of herd health initiated and supported by the Ministry of Rural Affairs. Currently, in Estonia, colistin as a B-category antimicrobial [3] is not indicated for the treatment of animals in the species and disease-specific antimicrobial treatment guidelines.

Many additional factors may affect the reduction of colistin consumption, but which could not be assessed in this study. The increasing need to reduce the use of CIAs in animals necessitates a need to monitor their use based on all available data. The general sales statistics have limited capacity to monitor long-term changes in AMU. There is no available data about the change of consumption of other antimicrobials in those pig farms, where colistin was used. However, the total consumption of antimicrobials in Estonia decreased from 2014 onwards. Further studies should focus on monitoring intervention measures at the farm-level and assessment of associations between AMU and herd health indicators [44]. In addition, we cannot give a clear explanation for the changes in colistin use in cattle and poultry. Due to the relatively small number of farms in Estonia, outbreaks or changes in treatment strategies in single farms can have a pronounced effect on the overall statistics. Due to commercial confidentiality, the specific details were not available for this study. At the national level, the data on the sales of veterinary antimicrobial products are important for guiding and supporting general policymaking decisions. The limitations of our study emphasize the importance of farm-level AMU monitoring, which is critical for driving antimicrobial stewardship, i.e., the establishment and implementation of measures aimed at combatting AMR by promoting responsible AMU practices [45]. In several European countries, farm-level monitoring is already established [46].

Achieving a minimum level of colistin use in food-producing animals avoiding an increase in the use of other antimicrobials and without jeopardizing animal welfare requires the use of preventive measures. Based on summaries of product characteristics (SPC) the primary indication for the oral administration of colistin is the treatment of gastrointestinal infections caused by colistin-sensitive non-invasive E. coli. Several studies have shown high AMU in weaned piglets $[47,48]$ and frequent colistin use in piglets and weaners in some countries [49]. Diseases as post-weaning diarrhea could be prevented. Vaccination against $E$. coli could be an important factor implicitly reducing the demand for colistin use in pigs. The European Centre for Disease Prevention and Control (ECDC), the European Food Safety Authority (EFSA), and the EMA joint scientific opinion pointed out that the use of CIAs in food-producing animals is the relevant indicator in assessing the progress in reducing AMU and AMR in humans and animals [50]. Accurate monitoring of diseases 
for which CIAs are indicated and finding the alternatives might be an effective method to reduce their use.

\section{Materials and Methods}

\subsection{Collection of Sales Data}

Currently available data on the sales of veterinary medicines in Estonia [51] are based on wholesaler's reports collected by the State Agency of Medicines and include total sales of veterinary medicines to veterinarians and pharmacies. The sales data are collected at package level per each year, including the name of the veterinary medicinal product, identification number of the product (package code), the active ingredient, pharmaceutical form, strength, package size, manufacturer, number of sold packages. Both antimicrobials and vaccination data are presented according to the Anatomical Therapeutic Chemical classification system for veterinary medicines [52].

\subsection{Collection of Data Allowing Differentiation of Target Species}

The national statistics of veterinary medicines of Estonia do not include information on sales by species. The ten years (2010-2019) sales data of colistin-containing products were collected from wholesalers, who sold colistin in those years, as sales to veterinarians treating only pigs, cattle, poultry or other species. Sales to veterinarians working in the mixed veterinary practice (treatment of different animal species) and sales to pharmacies are defined as sales to species unknown (includes sales to cattle, pigs, poultry and other species). Colistin sales data of wholesalers, who could not provide data by species, are defined as sales to species unknown. Due to commercial confidentiality, colistin sales data differentiating cattle and poultry as target species could not be published and the data are therefore merged for these two animal species. Data were collected and calculated according to the same principles as the national statistics.

\subsection{Calculation of Colistin Consumption Data}

Quantities of colistin were calculated for each product by multiplying the number of sold packages by the amount of active ingredient in each package and converted to milligram (mg) active ingredient. The standard conversion factor was used to convert international units (IU) to $\mathrm{mg}$ of the active ingredient when strength was given in IU. The number of sold doses of $E$. coli vaccines for pigs was calculated for each product by multiplying the number of sold packages by the number of vaccine doses in each package.

The population correction unit (PCU) was used as a denominator for sales data. The methodology of calculation of PCU is the same as in ESVAC reports [53]. PCU is a technical unit of measurement, which is calculated for each animal category by multiplying numbers of livestock animals and slaughtered animals by the theoretical weight at the time for the treatment.

The PCU (1 PCU $=1 \mathrm{~kg}$ of animal biomass) for pigs was calculated as follows:

$$
\text { PCUpigs }=\text { PCUdomestic }+ \text { PCUexport }- \text { PCUimport }
$$

where, PCUdomestic $=$ number of living sows $\times$ estimated weight at treatment + number of slaughtered pigs $\times$ estimated weight at the treatment, PCUexport $=$ number of pigs exported for slaughtering or fattening $\times$ estimated weight at the treatment and PCUimport $=$ number of pigs imported for slaughtering or fattening $\times$ estimated weight at the treatment

For calculation of PCU for pigs, the following standardised average weight in kilograms was used: living sows $240 \mathrm{~kg}$, slaughtered pigs $65 \mathrm{~kg}$, imported-exported pigs for slaughter $65 \mathrm{~kg}$, and imported-exported pigs for fattening $25 \mathrm{~kg}$ [53]. 
For transnational comparison of colistin consumption, the sales data of colistin are expressed in milligrams of active ingredient per kilogram of estimated weight at the treatment of livestock and slaughtered animals (mg/PCU):

$$
\text { Total consumption }=\frac{\text { Total amount of sold colistin in } \mathrm{mg}}{\text { Total PCU in } \mathrm{kg}}
$$

The amount of sold colistin for pigs included only sales of colistin to pig farms, and species unknown are not included in the calculations:

$$
\text { Consumption in pigs }=\frac{\text { Amount of sold colistin for pigs in } \mathrm{mg}}{P C U \text { pigs in } \mathrm{kg}}
$$

\subsection{Statistical Analysis}

The data of colistin and E. coli vaccine consumption over years 2010-2019 was inserted into Microsoft Excel (2016) spreadsheet, and the descriptive analysis was compiled by using the corresponding functions.

In order to analyse the association between colistin and E. coli vaccine consumption in pigs in 2010-2019, a time-series analysis was applied by using Stata ${ }^{\circledR}$ MP14.2 (StataCorp, College Station, TX, USA). To sort and index the data by years a 'tsset' command was used. A linear model with autoregressive integrated moving average (ARIMA) was created. To estimate the moving-average order (q) a correlogram was composed using the 'ac' command. By using a partial correlogram ('pac' command) an autoregressive order (p) was specified. The final ARIMA model used colistin consumption (mg/PCU) as an outcome variable, number of E. coli doses $(\times 10,000$ doses $)$ as a predictor variable, the moving-average order $(\mathrm{q})=0$, integrated (difference) order $(\mathrm{d})=1$ and autoregressive $\operatorname{order}(\mathrm{p})=0$.

\section{Conclusions}

The responsible use of antimicrobials promotes avoiding CIAs in food-producing animals and finding alternatives to the highest priority CIAs as colistin. This study revealed a remarkable increase in colistin consumption from 2010 to 2013 and a sharp reduction thereafter in Estonian production animals, whereas that was largely the result of changes in colistin use in pig production. Achieving a minimum level of colistin use in food-producing animals while simultaneously avoiding an increase in the use of other antimicrobials and without jeopardizing animal welfare requires the use of preventive measures. Among other improvements at the farm level, vaccination of piglets against E. coli strains could contribute to reduced colistin use in pig production. Accurate monitoring of the diseases for which CIAs are indicated and searching for alternatives might be an effective way to reduce their use.

Author Contributions: Conceptualization, M.S.; methodology, M.S. and K.M.; formal analysis, M.S. and K.M.; writing — original draft preparation, M.S.; writing_-review and editing, M.S., K.M. and P.K.; funding acquisition, P.K. All authors have read and agreed to the published version of the manuscript.

Funding: This research was supported by the Estonian Research Council project L190172VLKM (RITA1/02-75-03).

Institutional Review Board Statement: No animals or patients were used in the study and no personal information was collected, therefore ethical review and approval were waived for this study.

Data Availability Statement: The data presented in this study are available on request from the corresponding author.

Acknowledgments: The authors would like to thank the Estonian State Agency of Medicines and Estonian wholesalers. Comments by Marek Sammul (University of Tartu, Narva College) are appreciated.

Conflicts of Interest: The authors declare no conflict of interest. 


\section{References}

1. Scott, H.M.; Acuff, G.; Bergeron, G.; Bourassa, M.W.; Gill, J.; Graham, D.W.; Kahn, L.H.; Morley, P.S.; Salois, M.J.; Simjee, S.; et al. Critically important antibiotics: Criteria and approaches for measuring and reducing their use in food animal agriculture. Ann. N. Y. Acad. Sci. 2019, 1441, 8-16. [CrossRef] [PubMed]

2. World Health Organisation. Critically Important Antimicrobials for Human Medicine. 2018. Available online: https://apps.who. int/iris/bitstream/handle/10665/312266/9789241515528-eng.pdf (accessed on 3 August 2020).

3. European Medicines Agency, Antimicrobial Advice ad hoc Expert Group (EMA/AMEG). Categorisation of Antibiotics Used in Animals Promotes Responsible Use to Protect Public and Animal Health. (EMA/688114/2020). Available online: https: / / www.ema.europa.eu/en/documents/report/categorisation-antibiotics-european-union-answer-request-europeancommission-updating-scientific_en.pdf (accessed on 15 February 2020).

4. Koyama, Y.; Kurosasa, A.; Tsuchiya, A.; Takakuta, K. A new antibiotic colist $\in$ produced by spore-forming soil bacteria. J. Antibiot. 1950, 3, 457-458.

5. Biswas, S.; Brunel, J.-M.; Dubus, J.-C.; Reynaud-Gaubert, M.; Rolain, J.-M. Colistin: An update on the antibiotic of the 21st century. Expert Rev. Anti-Infect. Ther. 2012, 10, 917-934. [CrossRef]

6. Catry, B.; Cavaleri, M.; Baptiste, K.; Grave, K.; Grein, K.; Holm, A.; Jukes, H.; Liebana, E.; Navas, A.L.; Mackay, D.; et al. Use of colistin-containing products within the European Union and European Economic Area (EU/EEA): Development of resistance in animals and possible impact on human and animal health. Int. J. Antimicrob. Agents 2015, 46, 297-306. [CrossRef]

7. Callens, B.; Persoons, D.; Maes, D.; Laanen, M.; Postma, M.; Boyen, F.; Haesebrouck, F.; Butaye, P.; Catry, B.; Dewulf, J. Prophylactic and metaphylactic antimicrobial use in Belgian fattening pig herds. Prev. Veter. Med. 2012, 106, 53-62. [CrossRef] [PubMed]

8. Rhouma, M.; Beaudry, F.; Thériault, W.; Letellier, A. Colistin in Pig Production: Chemistry, Mechanism of Antibacterial Action, Microbial Resistance Emergence, and One Health Perspectives. Front. Microbiol. 2016, 7, 1789. [CrossRef]

9. Rhouma, M.; Fairbrother, J.M.; Beaudry, F.; Letellier, A. Post weaning diarrhea in pigs: Risk factors and non-colistin-based control strategies. Acta Veter. Scand. 2017, 59, 1-19. [CrossRef] [PubMed]

10. Timmerman, T.; Dewulf, J.; Catry, B.; Feyen, B.; Opsomer, G.; de Kruif, A.; Maes, D. Quantification and evaluation of antimicrobial drug use in group treatments for fattening pigs in Belgium. Prev. Veter.-Med. 2006, 74, 251-263. [CrossRef] [PubMed]

11. Rhouma, M.; Beaudry, F.; Thériault, W.; Bergeron, N.; Beauchamp, G.; Laurent-Lewandowski, S.; Fairbrother, J.M.; Letellier, A. In vivo therapeutic efficacy and pharmacokinetics of colistin sulfate in an experimental model of enterotoxigenic Escherichia coli infection in weaned pigs. Veter. Res. 2016, 47, 1-11. [CrossRef]

12. Fairbrother, J.M.; Nadeau, É.; Gyles, C.L. Escherichia coliin postweaning diarrhea in pigs: An update on bacterial types, pathogenesis, and prevention strategies. Anim. Health Res. Rev. 2005, 6, 17-39. [CrossRef]

13. Koch-Weser, J.; Sidel, V.W.; Federman, E.B.; Kanarek, P.; Finer, D.C.; Eaton, A.E. Adverse effects of sodium colistimethate. Manifestations and specific reaction rates during 317 courses of therapy. Ann. Int. Med. 1970, 72, 857-868. [CrossRef]

14. Liu, Y.-Y.; Wang, Y.; Walsh, T.R.; Yi, L.-X.; Zhang, R.; Spencer, J.; Doi, Y.; Tian, G.; Dong, B.; Huang, X.; et al. Emergence of plasmid-mediated colistin resistance mechanism MCR-1 in animals and human beings in China: A microbiological and molecular biological study. Lancet Infect. Dis. 2016, 16, 161-168. [CrossRef]

15. Rhouma, M.; Beaudry, F.; Letellier, A. Resistance to colistin: What is the fate for this antibiotic in pig production? Int. J. Antimicrob. Agents 2016, 48, 119-126. [CrossRef] [PubMed]

16. Wang, R.; Van Dorp, L.; Shaw, L.P.; Bradley, P.; Wang, Q.; Wang, X.; Jin, L.; Zhang, Q.; Liu, Y.; Rieux, A.; et al. The global distribution and spread of the mobilized colistin resistance gene mcr-1. Nat. Commun. 2018, 9, 1-9. [CrossRef] [PubMed]

17. Brauer, A.; Telling, K.; Laht, M.; Kalmus, P.; Lutsar, I.; Remm, M.; Kisand, V.; Tenson, T. Plasmid with Colistin Resistance Genemcr-1in Extended-Spectrum- $\beta$-Lactamase-Producing Escherichia coli Strains Isolated from Pig Slurry in Estonia. Antimicrob. Agents Chemother. 2016, 60, 6933-6936. [CrossRef]

18. European Medicines Agency (EMA). Updated Advice on the Use of Colistin Products in Animals within the European Union: Development of Resistance and Possible Impact on Human and Animal Health. (EMA/CVMP/CHMP/231573/2016). Available online: https:/ / www.ema.europa.eu/en/documents/scientific-guideline/updated-advice-use-colistin-products-animalswithin-european-union-development-resistance-possible_en-0.pdf (accessed on 15 May 2020).

19. Li, J.; Nation, R.L.; Turnidge, J.D.; Milne, R.W.; Coulthard, K.; Rayner, C.R.; Paterson, D.L. Colistin: The re-emerging antibiotic for multidrug-resistant Gram-negative bacterial infections. Lancet Infect. Dis. 2006, 6, 589-601. [CrossRef]

20. Andrade, F.F.; Silva, D.; Rodrigues, A.; Pina-Vaz, C. Colistin Update on Its Mechanism of Action and Resistance, Present and Future Challenges. Microorganisms 2020, 8, 1716. [CrossRef] [PubMed]

21. Dorado-García, A.; Mevius, D.J.; Jacobs, J.J.H.; Van Geijlswijk, I.M.; Mouton, J.W.; Wagenaar, J.A.; Heederik, D.J. Quantitative assessment of antimicrobial resistance in livestock during the course of a nationwide antimicrobial use reduction in the Netherlands. J. Antimicrob. Chemother. 2016, 71, 3607-3619. [CrossRef]

22. Wang, Y.; Xu, C.; Zhang, R.; Chen, Y.; Shen, Y.; Hu, F.; Liu, D.; Lu, J.; Guo, Y.; Xia, X.; et al. Changes in colistin resistance and mcr-1 abundance in Escherichia coli of animal and human origins following the ban of colistin-positive additives in China: An epidemiological comparative study. Lancet Infect. Dis. 2020, 20, 1161-1171. [CrossRef]

23. EUR-Lex. Regulation (EC) No 1831/2003 of the European Parliament and of the Council of 22 September 2003 on Additives for Use in Animal Nutrition. Available online: http:/ / data.europa.eu/eli/reg/2003/1831/oj (accessed on 25 February 2020). 
24. Peterson, L. Squeezing the antibiotic balloon: The impact of antimicrobial classes on emerging resistance. Clin. Microbiol. Infect. 2005, 11, 4-16. [CrossRef]

25. Jensen, L.M. The 'Balloon Effect'-Intervention Triggers Shift between Antimicrobial Classes. How Interventions on One Substance Effect the Use of Other Substances-For Gastrointestinal Disorders in Weaner Pigs. Presented at the Acting Second International Conference „Quantification, Benchmarking and Stewardship of Veterinary Antimicrobial Usage“", Bern, Switzerland, July 2019; Available online: https:/ / aacting.org/swfiles/files/Jensen_AACTING_Bern_60.pdf (accessed on 15 December 2020).

26. Allen, H.K.; Levine, U.Y.; Looft, T.; Bandrick, M.; Casey, T.A. Treatment, promotion, commotion: Antibiotic alternatives in food-producing animals. Trends Microbiol. 2013, 21, 114-119. [CrossRef]

27. Postma, M.; Stärk, K.D.; Sjölund, M.; Backhans, A.; Beilage, E.G.; Lösken, S.; Belloc, C.; Collineau, L.; Iten, D.; Visschers, V.; et al. Alternatives to the use of antimicrobial agents in pig production: A multi-country expert-ranking of perceived effectiveness, feasibility and return on investment. Prev. Veter. Med. 2015, 118, 457-466. [CrossRef]

28. Kruse, A.B.; Nielsen, L.R.; Alban, L. Vaccination against Actinobacillus pleuropneumoniae as an alternative strategy to antimicrobial use in Danish pig herds. In Proceedings of the Safepork 2015 Proceedings, Epidemiology and Control of Hazards in Pork Production Chain-SAFEPORK, One Health Approach under a Concept of Farm to Fork, Porto, Portugal, 7-10 September 2015; pp. 357-359. [CrossRef]

29. Bak, H.; Rathkjen, P.H. Reduced use of antimicrobials after vaccination of pigs against porcine proliferative enteropathy in a Danish SPF herd. Acta Veter. Scand. 2009, 51, 1-4. [CrossRef]

30. Van Dommelen, I.; Wertenbroek, N. Reduction of antibiotics after implementing PCV2 vaccination on 460 sow Dutch pigfarm. In Proceedings of the 114th International Conference on the Epidemiology and Control of Biological, Chemical and Physical Hazards in Pigs and Pork, Maastricht, The Netherlands, 19-22 June 2011; pp. 336-338. [CrossRef]

31. Raith, J.; Trauffler, M.; Firth, C.L.; Lebl, K.; Schleicher, C.; Köfer, J. Influence of porcine circovirus type 2 vaccination on the level of antimicrobial consumption on 65 Austrian pig farms. Veter. Rec. 2016, 178, 504. [CrossRef] [PubMed]

32. Van Looveren, F.; De Jonghe, E.; Maass, P.; De Backer, P. Reduction of antibiotic use after implementation of Ingelvac®PRRS MLV piglet vaccination in a Belgian wean to finish farm. In Proceedings of the Safepork 2015 Proceedings, Epidemiology and Control of Hazards in Pork Production Chain-SAFEPORK, One Health Approach under a Concept of Farm to Fork, Porto, Portugal, 7-10 September 2015; pp. 353-355. [CrossRef]

33. Raasch, S.; on the behalf of the MINAPIG Consortium; Collineau, L.; Postma, M.; Backhans, A.; Sjölund, M.; Belloc, C.; Emanuelson, U.; Beilage, E.G.; Stärk, K.; et al. Effectiveness of alternative measures to reduce antimicrobial usage in pig production in four European countries. Porc. Health Manag. 2020, 6, 1-12. [CrossRef] [PubMed]

34. Aasmäe, B.; Kalmus, P.; Onoper, A.; Lehtla, A.; Häkkinen, L.; Birkenfeldt, M. Soovitused antibiootikumide mõistlikuks kasutamiseks eri loomaliikide bakteriaalsete infektsioonide ravis. Eesti Loomaarstlik Ringvaade 2012, 3, 18-24.

35. Ministry of Rural Affairs. Juhend Antibiootikumide Kasutamiseks Põllumajandusloomadel. Clinical Guideline. 2020. Available online: https: / / www.agri.ee/sites/default/files/content/valjaanded/juhend-2020-antibiootikumiravi-loomad.pdf (accessed on 15 November 2020).

36. Statistics Estonia. PM1720: Births of Calves and Piglets Per Year. Available online: https://andmed.stat.ee/en/stat/ majandus_pellumajandus_pellumajandussaaduste-tootmine_loomakasvatussaaduste-tootmine/PM1720 (accessed on 17 December 2020).

37. European Surveillance of Veterinary Antimicrobial Consumption (ESVAC). Sales of Veterinary Antimicrobial Agents in 31 European Countries in 2018 (EMA/24309/2020). Available online: https://www.ema.europa.eu/en/documents/report/sales-veterinaryantimicrobial-agents-31-european-countries-2018-trends-2010-2018-tenth-esvac-report_en.pdf (accessed on 25 October 2020).

38. Stege, H.; Bager, F.; Jacobsen, E.; Thougaard, A. VETSTAT—-the Danish system for surveillance of the veterinary use of drugs for production animals. Prev. Veter. Med. 2003, 57, 105-115. [CrossRef]

39. Dupont, N.; Diness, L.H.; Fertner, M.; Kristensen, C.S.; Stege, H. Antimicrobial reduction measures applied in Danish pig herds following the introduction of the "Yellow Card" antimicrobial scheme. Prev. Veter. Med. 2017, 138, 9-16. [CrossRef] [PubMed]

40. European Surveillance of Veterinary Antimicrobial Consumption (ESVAC). Trends by Country. Country Reports on Sales Trends 2010-2018. Available online: https:/ / www.ema.europa.eu/en/veterinary-regulatory/overview/antimicrobial-resistance/ european-surveillance-veterinary-antimicrobial-consumption-esvac\#trends-by-country-section (accessed on 25 October 2020).

41. Temtem, C.; Kruse, A.B.; Nielsen, L.R.; Pedersen, K.S.; Alban, L. Comparison of the antimicrobial consumption in weaning pigs in Danish sow herds with different vaccine purchase patterns during 2013. Porc. Health Manag. 2016, 2, 1-11. [CrossRef] [PubMed]

42. Nurmoja, I.; Petrov, A.; Breidenstein, C.; Zani, L.; Forth, J.H.; Beer, M.; Kristian, M.; Viltrop, A.; Blome, S. Biological characterization of African swine fever virus genotype II strains from north-eastern Estonia in European wild boar. Transbound. Emerg. Dis. 2017, 64, 2034-2041. [CrossRef]

43. Agricultural Registers and Information Board. Available online: https://www.pria.ee/en/registers (accessed on 10 January 2021).

44. Collineau, L.; Rojo-Gimeno, C.; Léger, A.; Backhans, A.; Loesken, S.; Nielsen, E.; Postma, M.; Emanuelson, U.; Beilage, E.; Sjölund, M.; et al. Herd-specific interventions to reduce antimicrobial usage in pig production without jeopardising technical and economic performance. Prev. Veter. Med. 2017, 144, 167-178. [CrossRef]

45. Dyar, O.J.; Huttner, B.; Schouten, J.; Pulcini, C.; ESGAP (ESCMID Study Group for Antimicrobial stewardship). What is antimicrobial stewardship? Clin. Microbiol. Infect. 2017, 23, 793-798. [CrossRef] [PubMed] 
46. Sanders, P.; Vanderhaeghen, W.; Fertner, M.; Fuchs, K.; Obritzhauser, W.; Agunos, A.; Carson, C.; Høg, B.B.; Andersen, V.D.; Chauvin, C.; et al. Monitoring of Farm-Level Antimicrobial Use to Guide Stewardship: Overview of Existing Systems and Analysis of Key Components and Processes. Front. Veter.-Sci. 2020, 7, 540. [CrossRef]

47. Sjölund, M.; Postma, M.; Collineau, L.; Lösken, S.; Backhans, A.; Belloc, C.; Emanuelson, U.; Beilage, E.; Stärk, K.; Dewulf, J. Quantitative and qualitative antimicrobial usage patterns in farrow-to-finish pig herds in Belgium, France, Germany and Sweden. Prev. Veter. Med. 2016, 130, 41-50. [CrossRef] [PubMed]

48. Sarrazin, S.; Joosten, P.; Van Gompel, L.; Luiken, R.E.C.; Mevius, D.J.; Wagenaar, J.A.; Heederik, D.J.J.; Dewulf, J.; Wagenaar, J.; Graveland, H.; et al. Quantitative and qualitative analysis of antimicrobial usage patterns in 180 selected farrow-to-finish pig farms from nine European countries based on single batch and purchase data. J. Antimicrob. Chemother. 2019, 74, 807-816. [CrossRef]

49. Van Rennings, L.; Von Münchhausen, C.; Ottilie, H.; Hartmann, M.; Merle, R.; Honscha, W.; Käsbohrer, A.; Kreienbrock, L. Cross-Sectional Study on Antibiotic Usage in Pigs in Germany. PLoS ONE 2015, 10, e0119114. [CrossRef] [PubMed]

50. European Centre for Disease Prevention and Control (ECDC); European Food Safety Authority (EFSA); European Medicines Agency (EMA). ECDC, EFSA and EMA Joint Scientific Opinion on a List of Outcome Indicators as Regards Surveillance of Antimicrobial Resistance and Antimicrobial Consumption in Humans and Food-Producing Animals. EFSA J. 2017,15 , e05017.

51. State Agency of Medicines. Statistics on Veterinary Medicines. Available online: https://ravimiamet.ee/en/statistics-veterinarymedicines (accessed on 14 June 2020).

52. WHO Collaborating Centre for Drug Statistics Methodology. ATCvet Classification. Available online: https://www.whocc.no/ atcvet/atcvet_index/ (accessed on 25 October 2020).

53. European Surveillance of Veterinary Antimicrobial Consumption (ESVAC). Trends in the Sales of Veterinary Antimicrobial Agents in Nine European Countries 2005-2009. (EMA/238630/2011). Available online: https://www.ema.europa.eu/en/documents/ report/trends-sales-veterinary-antimicrobial-agents-nine-european-countries_en.pdf (accessed on 25 October 2020). 